\title{
Rooting Pattern and Productivity of Maize under High Density Planting
}

\author{
R. Raja Priya* and R. Krishnan \\ Department of Agronomy, Agricultural College and Research Institute, Tamil Nadu \\ Agricultural University, Coimbatore, Tamil Nadu, India \\ *Corresponding author
}

\section{A B S T R A C T}

\begin{tabular}{|l|}
\hline K e y w o r d s \\
Volume, Root, \\
$\begin{array}{l}\text { Density, Population, } \\
\text { Fertilizer }\end{array}$ \\
\hline Article Info \\
\hline $\begin{array}{l}\text { Accepted: } \\
18 \text { August } 2020 \\
\text { Available Online: } \\
\text { 10 September } 2020\end{array}$ \\
\hline
\end{tabular}

A field experiment was conducted at Eastern Block Farm, Department of Agronomy, Tamil Nadu Agricultural University, Coimbatore during kharif 2017 and 2018 (July to November) to identify the rooting pattern and productivity of maize under high density planting. The field experiment was laid out in randomized block design and replicated thrice. This study comprised of nine treatments which include four mixtures of spacings with one or two seedlings per hill and diverse fertilizer doses. The result of this study shows positive impact on root parameters like length, volume and dry weight. Higher root length was observed with crop geometry of $60 \mathrm{~cm} \times 25 \mathrm{~cm}$ sown at two seedlings hill ${ }^{-1}$ with application of $200 \% \mathrm{RDF}$, root volume was noticed under plant spacing of $60 \mathrm{~cm} \times$ $25 \mathrm{~cm}$ maintained at one seedling hill ${ }^{-1}$ with $100 \%$ RDF and wider spacing of $60 \mathrm{~cm} \times 40$ $\mathrm{cm}$ with two seedlings hill ${ }^{-1}$ with $150 \%$ RDF registered higher dry weight of roots during both the years of study. With respect to yield, higher grain and stover yield was produced under closer spacing $(30 \mathrm{~cm} \times 25 \mathrm{~cm})$ with one seedling hill ${ }^{-1}$ with application $200 \%$ RDF.

\section{Introduction}

Maize crop is less water demanding than cereals and being a ' $\mathrm{C}_{4}$ ', it gives higher yield hectare $^{-1}$ in a shorter period and can be grown in any season. The multiple utilities of maize as a 'food', 'fodder' and 'feed' makes it further more demanded. The current maize production scenario highlights the presence of hybrid maize at about 65-70 per cent acreages and most of it accounts for feed and industrial purpose (Grain and Report, 2017). In India, about 50 to 55 per cent of the total maize production is consumed as food, 30 to 35 per cent for poultry, piggery and fish meal industry and 10 to 12 per cent to milling industry (Thakur et al., 2015). Maize grain contains about 72 per cent starch, 10 per cent protein, 4.8 per cent oil, 9.5 per cent fibre, 3 per cent sugar and 1.7 per cent ash (Rafiq et al., 2010).

Maize is cultivated in almost all types of agro-ecological regions and heavily on the south west monsoon. After paddy and wheat, maize is the third most grown cereal crop within India. States such as Karnataka, Rajasthan, Andhra Pradesh and Madhya Pradesh, contribute towards half of the total maize acreage in India. During the past two 
decades, southern states, especially Andhra Pradesh and Karnataka have become the major maize producing states (Kumar et al., 2013).

Area under maize production is increasing due to its high yielding potential and demand. Yield potential of maize mainly depends on its genetic potential as well as climatic condition and management practices like optimum plant population and judicious use of fertilizers. Among various management practices, the productivity of the system mainly depends on proper nutrient management. Low organic matter content in soil coupled with low and imbalanced application of macro nutrients to the crop limits the full potential of yield (Ghosh et al., 2003). Among nutrients, proper level, ratio, balanced and optimum use of nitrogen, phosphorus and potassium fertilizers are the prime importance in increasing the yields of cereals (Asghar et al., 2010).

Nitrogen is the most deficient primary nutrient in Indian soils. Nitrogen is a vital nutrient for the activity of plant organs. Thus, plant growth can be affected by the amount of nitrogen present in soil (Najm et al., 2012). Phosphorus is known to stimulate early and extensive development of root systems, which enables rapid maize growth and to mature early (Sankaran et al., 2005). Maize has responds greatly to potassium fertilizers. Therefore, proper management of potassium is essential to realize maximum potential of the crop because it plays an important role in activating various enzymes, translocation of food materials from source to sink effectively and disease resistant.

The response of crops to nutrient varies widely from place to place, depending upon the fertility level of soil and other environmental conditions. This necessitates the study on the response of crop to different levels of fertilizers. Optimum nutrient requirement will vary with plant population.

Grain yield of maize was most affected by plant density because it differ in response to plant population (Luque et al., 2006). Even under optimum growth conditions, most of the growth parameters of maize were affected by plant population. Therefore, population is considered a major factor for getting maximum yield (Sangakkara et al., 2004).

Increasing the productivity is an alternate way to meet out the demand for which the best method is adopting higher number of plants per unit area. Two seedlings hill ${ }^{-1}$ doubled the population as compared to recommended seedling and geometry (single seedling hill ${ }^{-1}$ ). Use of high plant densities per unit area increases interplant competition for inputs like water, nutrients which may influence the final yield of maize, so it requires more fertilizers. Maize is also an exhaustive crop, so two seedlings hill ${ }^{-1}$ requires higher dose of fertilizer to meet out its fertilizer requirement. Hence, to meet out nutrient requirement of crops under higher plant population per unit area, to maintain soil fertility and to increase the overall productivity, it can be supplemented with higher dose of fertilizers.

Under single seedling hill ${ }^{-1}$, roots have no competition between plants, whereas in high density planting by including two seedlings hill $^{-1}$ plants have competition even under below ground. To know the effect of high plant density on root behaviour the present study was formulated in maize.

\section{Materials and Methods}

Field trial was conducted during kharif season of 2017 and 2018 at Research Farm, Agricultural College and Research Institute, Coimbatore, Tamil Nadu. The experimental farm was geographically situated in North 
Western agro-climatic zone of Tamil Nadu at $11^{\circ} \mathrm{N}$ and $77^{\circ} \mathrm{E}$ with an altitude of $426.7 \mathrm{~m}$ above mean sea level.

The soil texture of the experimental field was sandy loam having $\mathrm{pH}$ of 8.54 and medium organic carbon $(0.60 \%)$. With consider to nutrient status, the soil was low in available nitrogen $\left(246.5 \mathrm{~kg} \mathrm{ha}^{-1}\right)$, medium in available phosphorus (11.5 $\left.\mathrm{kg} \mathrm{ha}^{-1}\right)$ and high in available potassium (420.8 $\mathrm{kg} \mathrm{ha}^{-1}$ ). Maize hybrid TNAU COH (M) 6 with duration of 110 days was used as test variety for maize.

The field experiment was laid out in randomized block design with three replications. High density of maize was achieved by altering plant spacing and adopting one or two seedlings per hill. The treatments comprised of four different population with various fertilizer doses viz., $60 \mathrm{~cm} \times 25 \mathrm{~cm}$ with one seeding hill ${ }^{-1}$ and 100 $\% \operatorname{RDF}\left(\mathrm{T}_{1}\right), 60 \mathrm{~cm} \times 25 \mathrm{~cm}$ with two seedlings hill ${ }^{-1}$ and $150 \% \operatorname{RDF}\left(\mathrm{T}_{2}\right), 60 \mathrm{~cm} \times$ $25 \mathrm{~cm}$ with two seedlings hill $^{-1}$ and $200 \%$ RDF $\left(\mathrm{T}_{3}\right), 60 \mathrm{~cm} \times 40 \mathrm{~cm}$ with two seedlings hill $^{-1}$ and $125 \%$ RDF $\left(\mathrm{T}_{4}\right), 60 \mathrm{~cm} \times 40 \mathrm{~cm}$ with two seedlings hill ${ }^{-1}$ and $150 \% \operatorname{RDF}\left(\mathrm{T}_{5}\right)$, $30 \mathrm{~cm} \times 25 \mathrm{~cm}$ with one seeding hill ${ }^{-1}$ and $150 \% \operatorname{RDF}\left(\mathrm{T}_{6}\right), 30 \mathrm{~cm} \times 25 \mathrm{~cm}$ with one seeding hill $^{-1}$ and $200 \% \operatorname{RDF}\left(\mathrm{T}_{7}\right), 45 \mathrm{~cm} \times$ $30 \mathrm{~cm}$ with one seeding hill ${ }^{-1}$ and $100 \%$ RDF $\left(\mathrm{T}_{8}\right)$ and $45 \mathrm{~cm} \times 30 \mathrm{~cm}$ with one seeding hill ${ }^{1}$ and $125 \% \operatorname{RDF}\left(\mathrm{T}_{9}\right)$.

Root characteristics like length, volume and dry weight was taken at 30,60 DAS and at 90 DAS of maize during both the years. The data were statistically analysed using "Analysis of variance test".

The critical difference at 5\% level of significance was calculated to find out the significance of different treatments over each other (Gomez and Gomez, 1984).

\section{Data collection}

\section{Length of root}

Five plants were carefully removed from the sampling rows of each treatment without damage to the roots by using digging fork to disturb the soil. The root length was measured from base to tip of the longest root of maize crop and expressed in $\mathrm{cm}$. In treatments with two seedlings hill ${ }^{-1}$, the average value of two plants was calculated and presented.

\section{Volume of root}

The roots scooped along with soil and it was washed in water carefully without damaging the roots and detached from the nodal bases. Excess moisture on the surface of the roots was removed by using blotting paper. Then, the volume of roots was measured by displacement techniques as suggested by Misra and Ahamed (1987).

Displacement technique - a special container with an overflow spout was filled with water until it overflowed from the spout and then roots were inserted into the container filled with water. The overflow volume of water was measured by using measuring cylinder and root volume was recorded. The values are expressed in cubic centimetres plant ${ }^{-1}$.

\section{Dry weight of root}

Five sample plants were removed from sampling rows and its roots were removed from the stem. The samples were air dried and oven dried for $80^{\circ} \pm 2^{0} \mathrm{C}$ till a constant weight was attained. The dry weight of roots was expressed in $\mathrm{g} \mathrm{hill}^{-1}$.

\section{Grain yield}

The cobs from the net plot area of each treatments were harvested separately. The harvested cobs were sundried, shelled, 
cleaned and grain yield was recorded for each treatment and expressed as $\mathrm{kg} \mathrm{ha}^{-1}$.

\section{Stover yield}

The maize stover in the net plot area of each treatment was cut close to the ground level and left in the field for three days for sun drying. Stover weight from each plot was recorded and expressed as $\mathrm{kg} \mathrm{ha}^{-1}$.

\section{Results and Discussion}

\section{Length of root}

The mean data on length of root $(\mathrm{cm})$ recorded at three growth stages of maize during 2017 and 2018 are presented in Fig. 1. At all the three stages of observation, higher root length was observed in $60 \mathrm{~cm} \times 25 \mathrm{~cm}$ two seedlings hill ${ }^{-1}$ with $200 \% \operatorname{RDF}\left(\mathrm{T}_{3}\right)$ during 2017 and 2018. This might be due to wider spacing with adequate fertilizer for their growth and development. Even though higher dose of fertilizer was given, competition would have occurred for space while adopting two seedlings hill ${ }^{-1}$ which in turn might have increased the length of roots. Application of higher RDF recorded higher root length and root dry weight of baby corn over 100\% RDF (Kumar et al., 2015). Geometry of $60 \mathrm{~cm} \times 25 \mathrm{~cm}$ - two seedlings hill $^{-1}$ with $150 \%$ RDF $\left(\mathrm{T}_{2}\right)$ was on par with $\mathrm{T}_{3}$. The lower root length $(40.8$ and $42.2 \mathrm{~cm}$ in 2017 and 2018, respectively at 90 DAS) was produced by $60 \mathrm{~cm} \times 25 \mathrm{~cm}$ - one seedling hill ${ }^{-1}$ with $100 \%$ RDF.

\section{Volume of root}

Different plant density and nutrient management practices had significantly influenced the volume of root in maize during both the years (Fig. 1). Among various treatments imposed, in 2017 and 2018, plant spacing of $60 \mathrm{~cm} \times 25 \mathrm{~cm}-$ one seedling hill ${ }^{-1}$ with $100 \% \mathrm{RDF}\left(\mathrm{T}_{1}\right)$ registered higher root volume (97.4 and $96.7 \mathrm{cc} \mathrm{plant}^{-1}$, respectively at 90 DAS).

Wider spacing and single seedling hill $^{-1}$ (optimum plant population per unit area than other treatments) would have made the plants to grow without competition between plants and better utilization of space, water, light and fertilizers consequently led to horizontal and vertical increase of below ground parts. Wider geometry increased the root spread, which eventually utilized the resources such as water, nutrient and space above ground (Hargilas, 2016). Lower root volume (72.2 and $75.0 \mathrm{cc} \mathrm{plant}^{-1}$ respectively at $90 \mathrm{DAS}$ ) was noticed under $60 \mathrm{~cm} \times 25 \mathrm{~cm} \mathrm{-} \mathrm{two}$ seedlings hill'-1 with $150 \% \operatorname{RDF}\left(\mathrm{T}_{2}\right)$.

\section{Dry weight of root}

In 2017 and 2018, at all the stages of observation, crop geometry of $60 \mathrm{~cm} \times 40 \mathrm{~cm}$ - two seedlings hill ${ }^{-1}$ with $150 \% \operatorname{RDF}\left(\mathrm{T}_{5}\right)$ recorded higher root dry weight (77.80 and $73.55 \mathrm{~g} \mathrm{hill}^{-1}$ in, respectively at $90 \mathrm{DAS}$ ) (Table 1). Increased weight of roots in wider spacing might be due to the availability of more space for the individual plant which could have given a chance with absorption of more nutrients which in turn increased growth.

The increase in $\mathrm{N}, \mathrm{P}_{2} \mathrm{O}_{5}$ and $\mathrm{K}_{2} \mathrm{O}$ dose from 0 to $100 \%$ recorded improvement in both below (root) and above ground (shoot) drymatter as observed by Ghosh et al., (2003). Further, lesser dry weight of roots was observed with closer spacing $(30 \mathrm{~cm} \times 25 \mathrm{~cm})$ planted with one seedling hill ${ }^{-1}$ with fertilized $150 \%$ RDF $\left(\mathrm{T}_{6}\right)$ due to decline in number of leaves, leaf area hill $^{-1}$ which led to less photosynthesis and less weight of plants. Similar result was reported by Amanullah and Shah (2010). 
Table.1 Effect of different plant population and nutrient management practices on dry weight of root $\left(\mathrm{g} \mathrm{hill}^{-1}\right)$ of maize during 2017 and 2018

\begin{tabular}{|c|c|c|c|c|c|c|c|c|c|}
\hline \multirow[t]{2}{*}{ Treatments } & \multicolumn{3}{|c|}{30 DAS } & \multicolumn{3}{|c|}{60 DAS } & \multicolumn{3}{|c|}{90 DAS } \\
\hline & 2017 & 2018 & Mean & 2017 & 2018 & Mean & 2017 & 2018 & Mean \\
\hline $\mathrm{T}_{1}: 60 \mathrm{~cm} \times 25 \mathrm{~cm}$ - one seedling hill ${ }^{-1}$ with $100 \% \mathrm{RDF}$ & 4.19 & 3.76 & 3.98 & 31.66 & 24.78 & 28.22 & 41.11 & 37.26 & 39.19 \\
\hline $\mathrm{T}_{2}: 60 \mathrm{~cm} \times 25 \mathrm{~cm}$ - two seedlings hill $^{-1}$ with $150 \% \mathrm{RDF}$ & 4.62 & 4.79 & 4.71 & 36.80 & 33.97 & 35.39 & 56.75 & 49.48 & 53.12 \\
\hline$T_{3}: 60 \mathrm{~cm} \times 25 \mathrm{~cm}$ - two seedlings hill $^{-1}$ with $200 \% \mathrm{RDF}$ & 5.40 & 5.66 & 5.53 & 40.09 & 36.94 & 38.52 & 60.35 & 53.17 & 56.76 \\
\hline$T_{4}: 60 \mathrm{~cm} \times 40 \mathrm{~cm}$ - two seedlings hill $^{-1}$ with $125 \% \mathrm{RDF}$ & 7.11 & 7.08 & 7.10 & 52.52 & 47.48 & 50.00 & 71.27 & 70.01 & 70.64 \\
\hline$T_{5}: 60 \mathrm{~cm} \times 40 \mathrm{~cm}$ - two seedlings hill $^{-1}$ with $150 \% \mathrm{RDF}$ & 7.78 & 7.70 & 7.74 & 53.05 & 48.11 & 50.58 & 77.80 & 73.55 & 75.68 \\
\hline $\mathrm{T}_{6}: 30 \mathrm{~cm} \times 25 \mathrm{~cm}$ - one seedling hill $^{-1}$ with $150 \% \mathrm{RDF}$ & 2.39 & 2.37 & 2.38 & 21.88 & 18.26 & 20.07 & 26.45 & 22.93 & 24.69 \\
\hline $\mathrm{T}_{7}: 30 \mathrm{~cm} \times 25 \mathrm{~cm}$ - one seedling hill ${ }^{-1}$ with $200 \% \mathrm{RDF}$ & 3.10 & 3.18 & 3.14 & 24.71 & 19.80 & 22.26 & 30.68 & 26.13 & 28.41 \\
\hline $\mathrm{T}_{8}: 45 \mathrm{~cm} \times 30 \mathrm{~cm}$ - one seedling hill $^{-1}$ with $100 \% \mathrm{RDF}$ & 3.69 & 3.48 & 3.59 & 30.50 & 22.75 & 26.63 & 37.58 & 34.11 & 35.85 \\
\hline $\mathrm{T}_{9}: 45 \mathrm{~cm} \times 30 \mathrm{~cm}$ - one seedling hill ${ }^{-1}$ with $125 \% \mathrm{RDF}$ & 4.10 & 3.75 & 3.93 & 30.96 & 23.29 & 27.13 & 39.94 & 35.54 & 37.74 \\
\hline SEd & 0.30 & 0.30 & 0.30 & 2.29 & 2.01 & 2.15 & 3.25 & 2.91 & 3.08 \\
\hline $\mathrm{CD}(\mathrm{P}=\mathbf{0 . 0 5})$ & 0.63 & 0.63 & 0.63 & 4.85 & 4.26 & 4.56 & 6.89 & 6.17 & 6.53 \\
\hline
\end{tabular}


Fig.1 Effect of plant density and nutrient management practices on root volume $\left(\mathrm{cc}\right.$ plant $\left.^{-1}\right)$ and root length $(\mathrm{cm})$ of maize
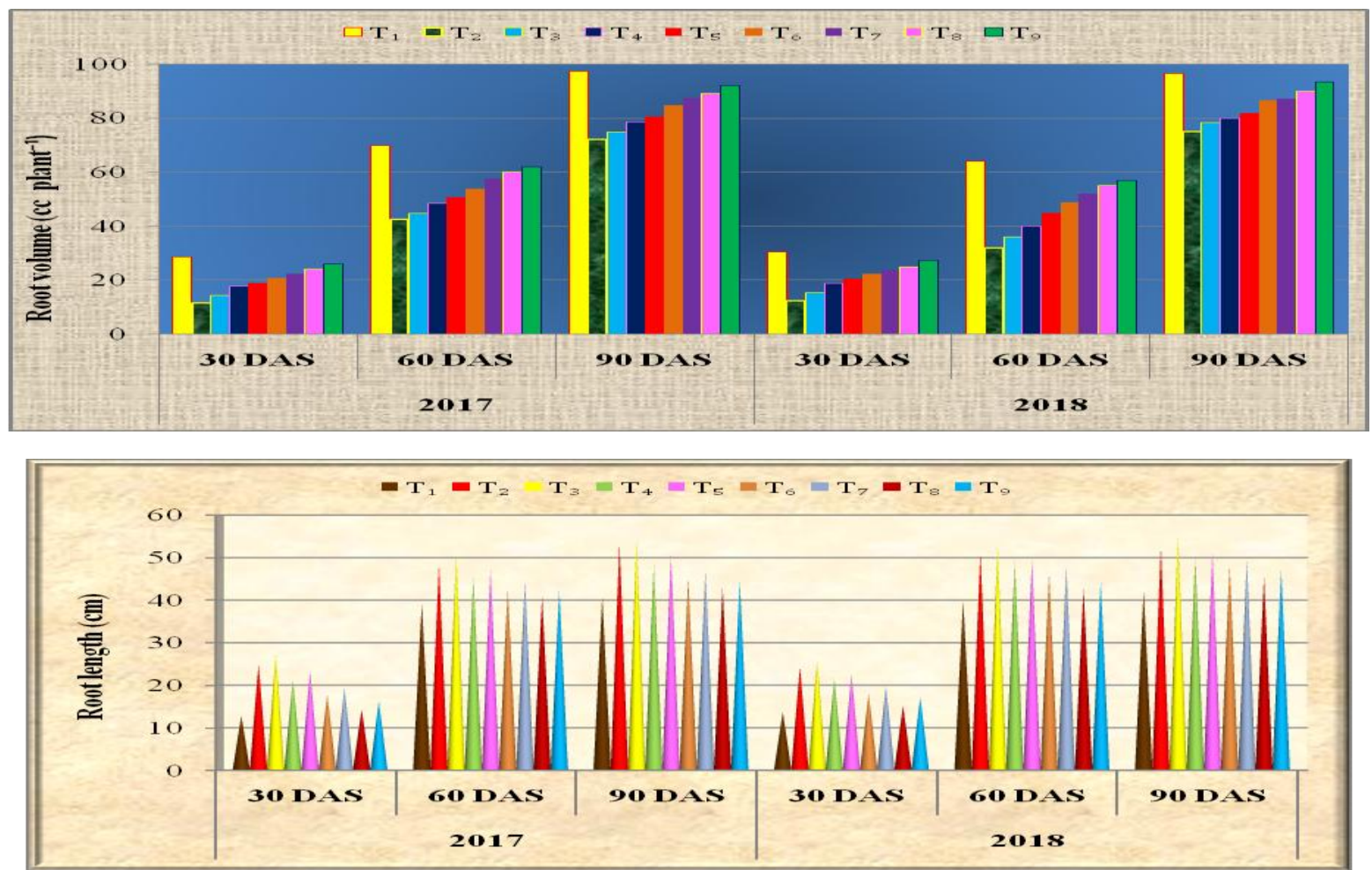

Fig.2 Effect of plant density and nutrient management practices on yield $\left(\mathrm{kg} \mathrm{ha}^{-1}\right)$ of maize

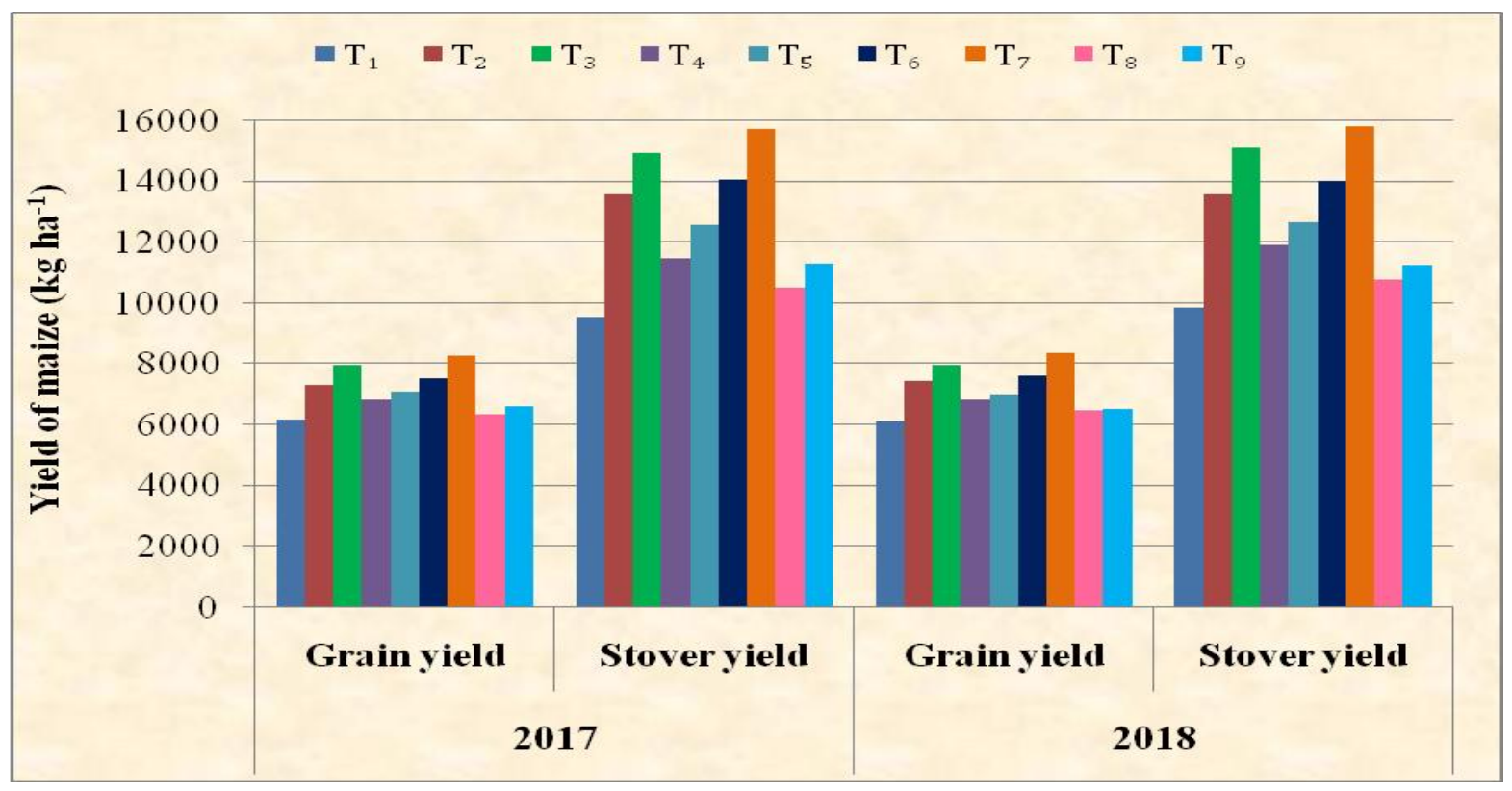




\section{Yield of Maize}

Data pertaining to grain and stover yield of maize under various plant density and fertilizer levels are given in Fig. 2.

In 2017 and 2018, closer geometry with higher RDF $\left(\mathrm{T}_{7}\right)$ produced higher grain and stover yield over the current recommended density and nutrient management $\left(\mathrm{T}_{1}\right)$. The next best treatment was wider spacing of two seedlings hill ${ }^{-1}$ with higher RDF of $60 \mathrm{~cm} \times$ $25 \mathrm{~cm}^{-}$two seedlings hill ${ }^{-1}$ with $200 \%$ RDF. Whereas, recommended practice (control) $\left(\mathrm{T}_{1}\right)$ produced lucidly lesser grain and stover yield. The percentage increase in grain yield $\mathrm{T}_{7}$ over control was 34.81 and 36.62 percentages, respectively in 2017 and 2018 (Raja Priya et al., 2019). Higher grain yield and stover yield was noticed while adopting single seedling hill $^{-1}$ and decreased row spacing $(30 \mathrm{~cm} \times 25 \mathrm{~cm})$ and increased fertilizer levels $\left(200 \%\right.$ RDF $\left.-\mathrm{T}_{7}\right)$. Single plant yield was less in this treatment, but it was compensated by number of plants hectare $^{-1}$. Generally grain yield increased with increasing planting density (Akbar et al., 2016). Stover yield increased with decrease in planting geometry was due to higher population and more number of plants in particular unit area. Positive influence of increased population on stover yield (Mangal et al., 2017).

From the results of this experiment it maybe concluded that, among various plant population and nutrient management practices, longer roots were produced under plant spacing of $60 \mathrm{~cm} \times 25 \mathrm{~cm}-$ two seedlings hill $^{-1}$ with $200 \% \mathrm{RDF}$ and higher volume of root was observed under plant geometry of $60 \mathrm{~cm} \times 25 \mathrm{~cm}$ - one seedling hill $^{-1}$ with $100 \%$ RDF. With respect to dry weight of maize roots, more was noticed with $60 \mathrm{~cm} \times 40 \mathrm{~cm}$ - two seedlings hill ${ }^{-1}$ with 150 $\%$ RDF. With increase in plant population by adopting closer spacing $(30 \mathrm{~cm} \times 25 \mathrm{~cm})$ by leaving one seeding hill ${ }^{-1}$ with application of increased fertilizer doses (200\% RDF) gives more yield of maize. These findings are useful for improving productivity of maize through adopting suitable plating geometry and nutrient management practices.

\section{References}

Akbar, M. A. Siddique, Mong Sanue Marma, M. Moksedur Rahman, M. Rafiqul Islam Molla, M. Jafar Ullah M. Matiar Rahman, A Mohammad Ashraf Hossain, and bdul Hamid. 2016. "Planting Arrangement, Population Density and Fertilizer Application Rate for White Maize (Zea mays L.) Production in Bandarban Valley." Agriculture, Forestry and Fisheries 5 (6):215-224.

Amanullah, and Paigham Shah. 2010. "Nitrogen rates and its time of application influence dry matter partitioning and grain yield in maize planted at low and high densities." Journal of plant nutrition 34 (2):224242.

Asghar, A, A Ali, WH Syed, M Asif, T Khaliq, and AA Abid. 2010. "Growth and yield of maize (Zea mays L.) cultivars affected by NPK application in different proportion." Pakistan journal of Science 62 (4):211-216.

Ghosh, PK, AK Bandyopadhyay, KM Tripati, and AK Mishra. 2003. "Effect of integrated management of farm yard manure, phosphor compost, poultry manure and inorganic fertilizers for rainfed jowar in vertisols of Central India." Indian journal of Agronomy 48:1-3.

Gomez, Kwanchai A, and Arturo A Gomez. 1984. Statistical procedures for agricultural research: John Wiley \& Sons. 
Grain, and Feed Annual Report. 2017.

Hargilas. 2016. "Effect of geometry and fertility levels on productivity and profitability of winter maize." The Bioscan 11 (1):673-679.

Kumar, Rakesh, JS Bohra, Amitesh Kumar Singh, and Narendra Kumawat. 2015. "Productivity, profitability and nutrientuse efficiency of baby corn (Zea mays) as influenced of varying fertility levels." Indian J. Agron 60 (2):285-290.

Kumar, Ranjit, K Srinivas, and N Sivaramane. 2013. "Assessment of the maize situation, outlook and investment opportunities in India." Country Report-Regional Assessment Asia (MAIZE-CRP), National Academy of Agricultural Research Management, Hyderabad, India:133.

Luque, Sergio F, Alfredo G Cirilo, and María E Otegui. 2006. "Genetic gains in grain yield and related physiological attributes in Argentine maize hybrids." Field Crops Research 95 (2-3):383-397.

Mangal, Mohammad Qayom, Mahmood Hemat, Habibu Llah Hamayoun, Sayed Rahim Ghafari, and Mohammad Naim Jalali. 2017. Response of maize varieties under variable planting geometry in Kandahar semi-arid situation. International Journal of Applied Research 3 (10):74-78.

Misra, and Ahamed. 1987. Root parameters and their measurement. In: Manual on irrigation agronomy:319-326.

Najm, Amir Ali, Mohammad Reza Haj Seyed Hadi, Faezeh Fazeli, Mohammad Taghi Darzi, and Alireza Rahi. 2012. "Effect of integrated management of nitrogen fertilizer and cattle manure on the leaf chlorophyll, yield, and tuber glycoalkaloids of Agria potato." Communications in Soil Science and Plant Analysis 43 (6):912-923.

Rafiq, Muhammad Asif, Asghar Ali, Muhammad Asghar Malik, and Mumtaz Hussain. 2010. "Effect of fertilizer levels and plant densities on yield and protein contents of autumn planted maize." Pak. J. Agri. Sci 47 (3):201208.

Raja Priya, R , Krishnan R, Srinivasan K and, and Shamugasundaram S. 2019. "Pressure of high plantig density ad fertilizer levels on maize growth and yield." International Journal of Chemical Studies 7 (3):2007 - 2010.

Sangakkara, UR, PSRD Bandaranayake, JN Gajanayake, and P Stamp. 2004. "Plant populations and yields of rainfed maize (Zea mays L) grown in wet and dry seasons of the Tropics." Maydica 49 (2):83-88.

Sankaran, N, S Meena, and N Sakthivel. 2005. "Input management in maize." Madras Agril. J 92 (7-9):464-468.

Thakur, Ashwani Kumar, Dushyant Singh Thakur, Rakesh Kumar Patel, Adikant Pradhan, and Prafull Kumar. 2015. Effect of different plant geometry and nitrogen levels, inrelation to growth characters, yield and economics on sweet corn (Zea mays sachharata 1.) At bastar plateau zone. The Bioscan 10 (3):1223-1226.

\section{How to cite this article:}

Raja Priya, R. and Krishnan, R. 2020. Rooting Pattern and Productivity of Maize under High Density Planting. Int.J.Curr.Microbiol.App.Sci. 9(09): 2538-2545.

doi: https://doi.org/10.20546/ijcmas.2020.909.318 